\title{
The Mississippi Alluvial Plain Aquifers: An Engine for Economic Activity
}

\begin{abstract}
U.S. Geological Survey (USGS) science supports groundwater resource management in the Mississippi Alluvial Plain (MAP) region. The USGS Science and Decisions Center is working with the Water Availability and Use Science Program (WAUSP) to integrate economics into a sophisticated model of groundwater in the region. The model will quantify the status of the groundwater system and help researchers, stakeholders, and decision-makers understand and manage groundwater resources. Including economics in the model will let users consider the influence of groundwater levels on regional economics and the effects of economic factors on the demand for groundwater.
\end{abstract}

Agriculture is a major source of economic activity in the Mississippi Alluvial Plain (MAP) region. The MAP region consists of parts of Arkansas, Mississippi, Louisiana, Tennessee, Kentucky, Illinois, and Missouri (fig. 1). Irrigated acreage in the region accounted for 14 percent of total U.S. agriculture in 2015 (Dieter and others, 2018). Major crops grown in the region include corn, cotton, rice, and soybeans. Catfish is an important aquaculture commodity.

Agriculture in the region relies on groundwater for irrigation. Approximately 65 percent of farmland in the region relies on groundwater from the Mississippi River Valley alluvial aquifer (MRVAA) for irrigation and aquaculture (Kebede and others, 2014). ${ }^{1}$ Irrigated acreage in the region is on the rise; from 2007 to 2012, irrigated acreage in Arkansas and Mississippi increased by about 7.7 and 20.7 percent, respectively (U.S. Department of Agriculture-National

${ }^{1}$ This groundwater withdrawal information is based on 2010 data from the Yazoo Mississippi Delta Joint Water Management District (http://www.ymd.org).

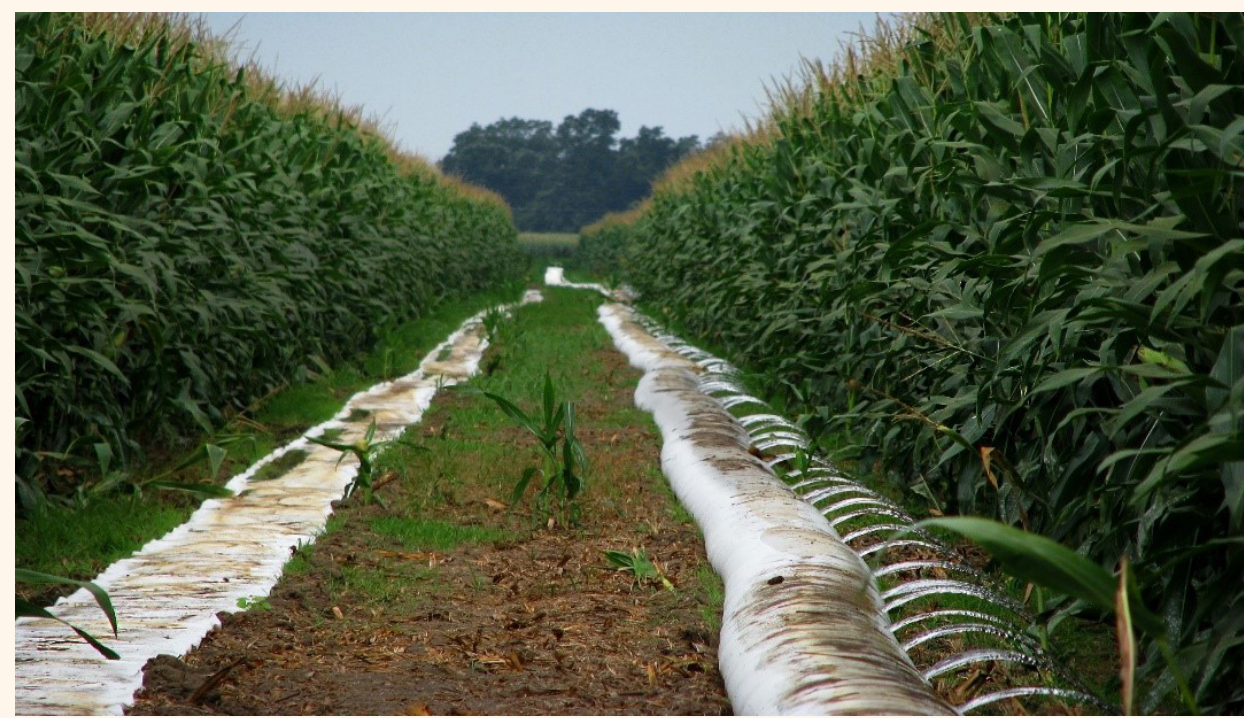

Corn irrigation in Mississippi. Photograph by the U.S. Geological Survey.

Agricultural Statistics Service [USDANASS], 2013). Seventy percent of corn, cotton, and soybean acres are irrigated, and rice is exclusively grown under flood irrigation systems (USDA-NASS, 2013). The MRVAA ranked second in groundwater use among aquifers in the Nation, accounting for 16 percent of the national, total groundwater withdrawals for irrigation in 2000 (Maupin and Barber, 2005); in 2015, groundwater use for irrigation was about 23 percent of the national total (Dieter and others, 2018).

Groundwater levels in the region are declining. For example, from 1940 to 1980 , groundwater-level declines due to large withdrawals ranged from 60 to 90 feet in the Grand Prairie and Cache River areas of Arkansas, and by 1982, declines ranged from 10 to 20 feet in northwestern Mississippi (Renken, 1998). Recent reports show a continuing trend of groundwater depletion. Schrader (2008) reported groundwaterlevel declines of as much as 50 feet in the MRVAA in parts of eastern Arkansas between 1927 and 2007. Clark and others (2011) reported that an approximately 216-square-mile (138,240-acre) area of the MRVAA showed declines of more than 100 feet from the predevelopment conditions to 2007. While groundwater levels decline, cumulative groundwater pumping from the MRVAA continues to rise (Clark and others, 2011). As groundwater withdrawal rates continue to outpace recharge, declining water levels in the aquifer coupled with rising energy prices will increase the pumping cost of regional irrigation.

Economic Impacts of Agriculture in the Region. The USGS evaluated the economic impacts of corn, cotton, soybeans, rice, and catfish production, hereafter referred to as "major commodities," for a 5-year period, $2013-17,{ }^{2}$ in the MAP region. Revenues from these major

${ }^{2}$ Only the 2017 economic impacts are presented in this fact sheet. All 2013-17 impacts are available as a USGS data release (Alhassan and others, 2019) at https://doi.org/10.5066/P9RW8Y2A. 


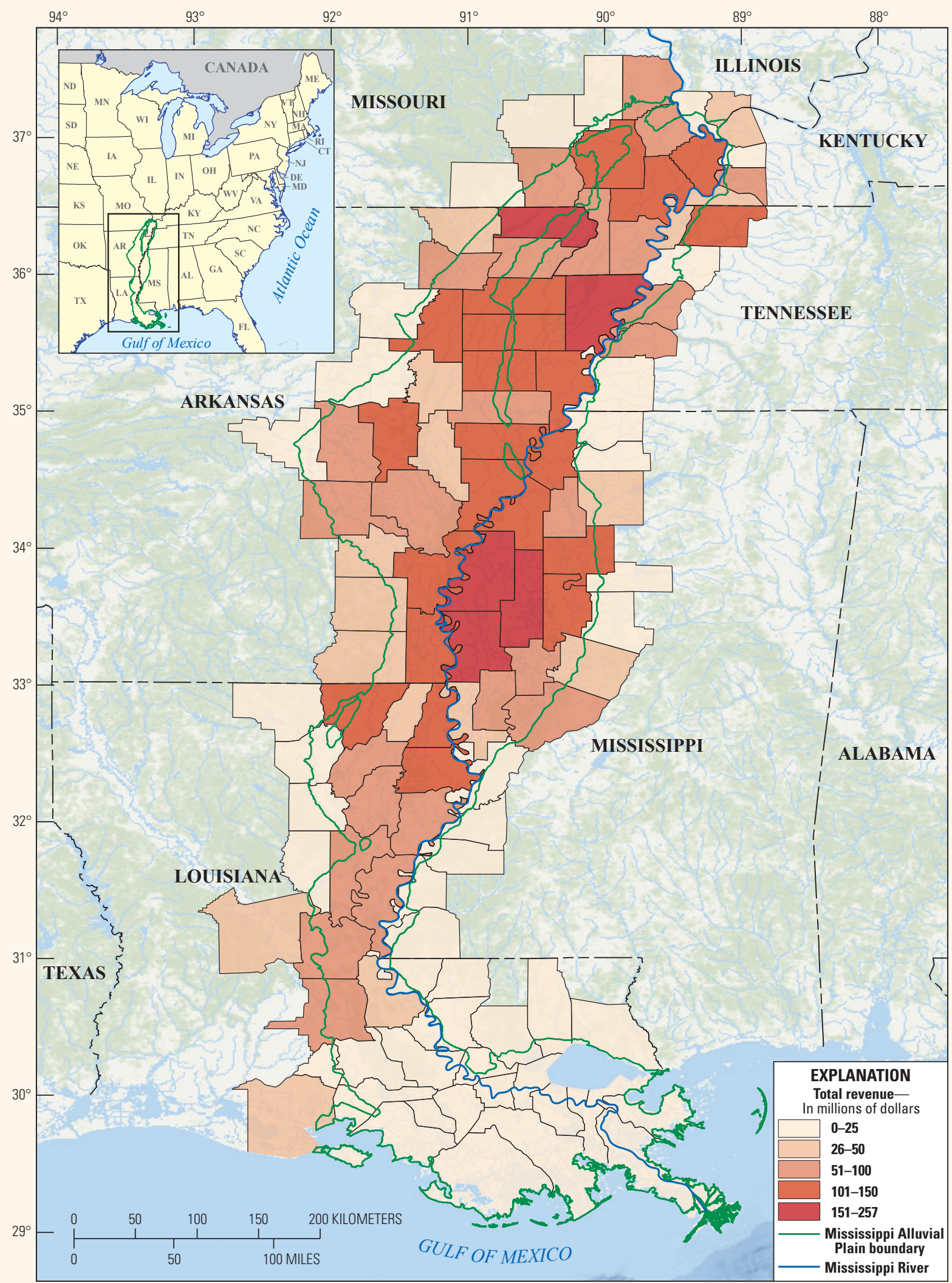

Base from Esri digital data, 2018, copyright 2018 Esri and its licensors

County boundaries from 2016 U.S. Census Bureau TIGER dataset

Mississippi River streamline from U.S. Geological Survey National Hydrography Dataset

MAP boundary from U.S. Environmental Protection Agency Level III Ecoregions dataset

Albers Equal-Area Conic projection, North American Datum of 1983

Figure 1. Map of total crop revenue by county for 2017 in the Mississippi Alluvial Plain region. Data from the U.S. Department of Agriculture-National Agricultural Statistics Service show that the most productive counties, by revenue, are in Arkansas and Mississippi. 
commodities were calculated by county in the seven States within the MAP region. These are the "direct" economic impacts. Also assessed were indirect and induced effects, such as the provision of goods and services to the crop and catfish sectors by other businesses (indirect) and the spending of labor income by workers in other industries that are indirectly impacted by the production sectors of the major commodities (induced). Each activity or sale generates additional jobs, salaries, and other benefits in the region, known commonly as multiplier impacts. The multiplier impact captures how production of a major crop or catfish benefits the larger regional economy. The total economic impact is the product of the direct effect and a multiplier. ${ }^{3}$

We used county-level annual outputs of the major crops for 2013 through 2017 (USDA-NASS, 2018). Output prices were obtained from USDA-NASS (2018), Mississippi State University (2018), and the University of Arkansas (2018). State-level inventories of food-sized catfish and prices were also obtained from USDA-NASS (2018, available only for Arkansas, Louisiana, and Mississippi). Data for some crops or for catfish were unavailable for some of the counties and States. The multipliers were obtained from the 2016 IMPLAN (Impact Analysis for Planning) Statelevel datasets (IMPLAN, 2016).

The economic impacts presented here should be interpreted as the minimum for the agricultural industry in the MAP region since they do not include livestock, small grains, pasture, vegetables, or other agricultural commodities. Table 1 lists total revenues for 2017, by commodity type and State, in millions of dollars. Based on the available data, total revenues from production of the major commodities in 2017 are $\$ 2.46$ billion in Arkansas and $\$ 1.80$ billion in Mississippi. These revenues correspond to 84 and 71 percent of the 2017 agricultural gross domestic products (GDPs) of Arkansas and Mississippi.

\footnotetext{
${ }^{3}$ We used Type II multipliers. Type II multipliers are final-demand multipliers and capture the indirect (interindustry) and induced (household-spending) impacts (Ambargis and Mead, 2012).
}

Table 1. State-level revenues from production of the major commodities (millions of dollars), Mississippi Alluvial Plain region, 2017.

[AR, Arkansas; IL, Illinois; KY, Kentucky; LA, Louisiana; MAP, Mississippi Alluvial Plain; MO, Missouri; MS, Mississippi; TN, Tennessee; - - no data]

\begin{tabular}{lrllllllr}
\hline Commodity & AR & IL & KY & LA & MO & MS & TN & $\begin{array}{r}\text { MAP } \\
\text { region }\end{array}$ \\
\hline Corn & $\$ 315$ & $\$ 11$ & $\$ 73$ & $\$ 302$ & $\$ 176$ & $\$ 267$ & $\$ 68$ & $\$ 1,212$ \\
Cotton & $\$ 349$ & - & - & $\$ 103$ & - & $\$ 321$ & $\$ 55$ & $\$ 829$ \\
Rice & $\$ 935$ & - & - & $\$ 88$ & - & $\$ 72$ & - & $\$ 1,096$ \\
Soybeans & $\$ 838$ & $\$ 32$ & $\$ 75$ & $\$ 591$ & $\$ 560$ & $\$ 953$ & $\$ 168$ & $\$ 3,217$ \\
Catfish & $\$ 21$ & - & - & - & - & $\$ 189$ & - & $\$ 210$ \\
\multicolumn{1}{c}{ Total } & $\mathbf{\$ 2 , 4 5 8}$ & $\mathbf{\$ 4 4}$ & $\mathbf{\$ 1 4 7}$ & $\mathbf{\$ 1 , 0 8 4}$ & $\mathbf{\$ 7 3 6}$ & $\mathbf{\$ 1 , 8 0 3}$ & $\mathbf{\$ 2 9 2}$ & $\mathbf{\$ 6 , 5 6 4}$ \\
\hline
\end{tabular}

Table 2. State-level total economic impacts of the major commodities (millions of dollars), Mississippi Alluvial Plain region, 2017.

[AR, Arkansas; IL, Illinois; KY, Kentucky; LA, Louisiana; MAP, Mississippi Alluvial Plain; MO, Missouri; MS, Mississippi; TN, Tennessee; — , no data]

\begin{tabular}{lrccccccc}
\hline Commodity & AR & IL & KY & LA & MO & MS & TN & $\begin{array}{c}\text { MAP } \\
\text { region }\end{array}$ \\
\hline Corn & $\$ 588$ & $\$ 20$ & $\$ 125$ & $\$ 618$ & $\$ 328$ & $\$ 494$ & $\$ 127$ & $\$ 2,301$ \\
Cotton & $\$ 653$ & - & - & $\$ 194$ & - & $\$ 585$ & $\$ 103$ & $\$ 1,535$ \\
Rice & $\$ 1,749$ & - & - & $\$ 180$ & - & $\$ 133$ & - & $\$ 2,063$ \\
Soybeans & $\$ 1,475$ & $\$ 56$ & $\$ 125$ & $\$ 1,087$ & $\$ 980$ & $\$ 1,639$ & $\$ 300$ & $\$ 5,662$ \\
Catfish & $\$ 35$ & - & - & - & - & $\$ 278$ & - & $\$ 314$ \\
\multicolumn{1}{c}{ Total } & $\mathbf{\$ 4 , 5 0 1}$ & $\mathbf{\$ 7 7}$ & $\mathbf{\$ 2 5 0}$ & $\mathbf{\$ 2 , 0 8 0}$ & $\mathbf{\$ 1 , 3 0 8}$ & $\mathbf{\$ 3 , 1 3 0}$ & $\mathbf{\$ 5 3 0}$ & $\mathbf{\$ 1 1 , 8 7 5}$ \\
\hline
\end{tabular}

Table 2 lists the total economic impacts, which include direct revenues as well as regional indirect and induced impacts. Arkansas and Mississippi represent most of the total economic impacts of the major commodities in the MAP region. In Arkansas, the total is $\$ 4.50$ billion, and in Mississippi the total is $\$ 3.13$ billion.

The total revenues and economic impacts of the MAP region by crop type are shown in figure 2 . The total revenue for the MAP region is $\$ 6.56$ billion, and the total economic impact is $\$ 11.88$ billion. Soybean crops contribute the most in terms of direct and total economic impacts in the region (attributable to both acreage and price). Corn and rice provide the next largest share, followed by cotton and catfish. Many other crops in the region provide additional revenue and contributions to the regional economy.

Because of the reliance on groundwater for irrigation in the MAP region, understanding the availability, use, and sustainability of the MRVAA is critical. The USGS is providing sophisticated analysis and modeling to increase knowledge of the MRVAA and the system water budgets at various levels of water use. Incorporating economic analyses provides additional information, including how changes in groundwater levels affect the cost of crop production in the region and how economic factors may influence water demand. Decision-makers and other stakeholders can use such information as they consider tradeoffs associated with different management actions. 


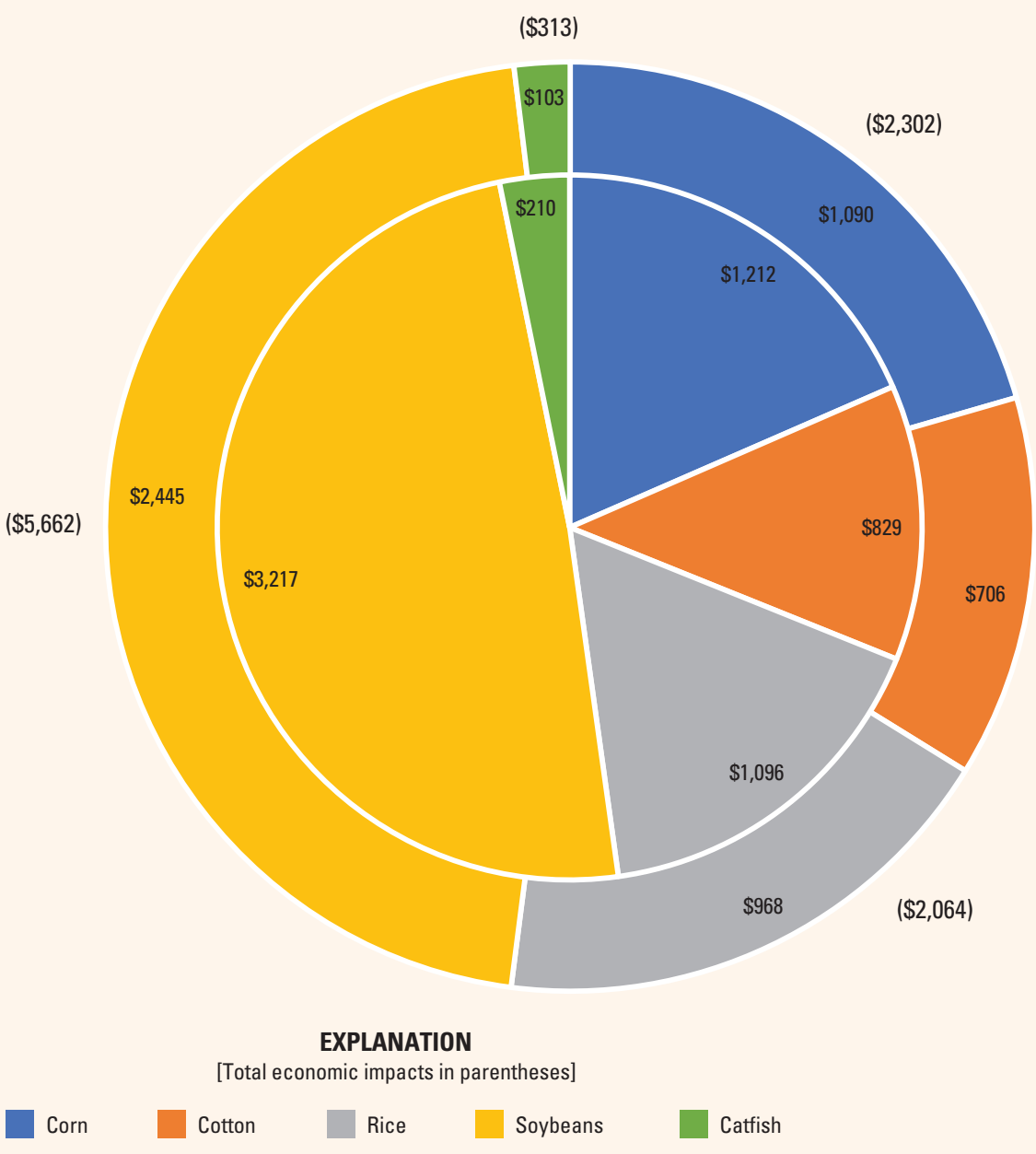

Figure 2. Total revenues (inner circle), indirect and induced economic impacts (outer circle), and total economic impacts (sum of inner and outer circles) of the major commodities (millions of dollars), Mississippi Alluvial Plain region, 2017.

\section{References Cited}

Alhassan, M., Lawrence, C.B., Richardson, S.M., and Pindilli, E.J., 2019, The Mississippi Alluvial Plain Aquifer-An engine for economic activity—Data: U.S. Geological Survey data release, https://doi.org/10.5066/P9RW8Y2A.

Ambargis, Z.O., and Mead, C.I., 2012, RIMS II-An essential tool for regional developers and planners: U.S. Department of Commerce, Bureau of Economic Analysis, variously paged.

Clark, B.R., Hart, R.M., and Gurdak, J.J., 2011, Groundwater availability of the Mississippi embayment: U.S. Geological Survey Professional Paper 1785, 62 p. (data and software).
Kebede, H., Fisher, D.K., Sui, R., and Reddy, K.N., 2014, Irrigation methods and scheduling in the delta region of Mississippi-Current status and strategies to improve irrigation efficiency: American Journal of Plant Sciences, v. 5, no. 20 , p. 2917-2928.

Maupin, M.A., and Barber, N.L., 2005, Estimated withdrawals from principal aquifers in the United States, 2000: U.S. Geological Survey Circular 1279, $46 \mathrm{p}$.

Mississippi State University, 2018, Budgets: Mississippi State University Department of Agricultural Economics datasets, accessed November 9, 2018, at https://agecon.msstate. edu/whatwedo/budgets.php.

Renken, R.A., 1998, Ground water atlas of the United States-Segment 5, Arkansas, Louisiana, Mississippi: U.S. Geological Survey Hydrologic Investigations Atlas 730-F, accessed July 31, 2018, at https://pubs.usgs. gov/ha/730f/report.pdf.

Schrader, T.P., 2008, Water levels and selected water-quality conditions in the Mississippi River Valley Alluvial Aquifer in eastern Arkansas, 2006: U.S. Geological Survey Scientific Investigations Report 2008-5092, 73 p.

University of Arkansas, 2018, Arkansas field crop enterprise budgets: University of Arkansas, Division of Agriculture, Research \& Extension database, accessed November 9, 2018, at https://www.uaex.edu/farm-ranch/economicsmarketing/farm-planning/budgets/crop-budgets.aspx.

U.S. Department of Agriculture-National Agricultural Statistics Service [USDA-NASS], 2018, Data and statistics: U.S. Department of Agriculture databases, accessed November 9, 2018, at https://www.nass.usda.gov/Data_and_Statistics/index.php.

U.S. Department of Agriculture-National Agricultural Statistics Service [USDA-NASS], 2014, Farm and ranch irrigation survey (2013) - Volume 3, special studies, part 1: U.S. Department of Agriculture 2012 Census of Agriculture, AC-12-SS-1, 214 p. plus appendixes, accessed July 31, 2018, at https://www.agcensus.usda. gov/Publications/2012/Online_Resources/ Farm_and_Ranch_Irrigation_Survey/fris 13.pdf.

\section{The USGS Science and Decisions Center is an interdisciplinary organization advancing the use of science in natural resource decision making. For more information, please contact:}

Science and Decisions Center

U.S. Geological Survey

913 National Center

Reston, VA 20192

Email: gs_emeh_sdc@usgs.gov

Home page: https://www2.usgs.gov/sde/

By Mustapha Alhassan, Collin Lawrence, Steven Richardson, and Emily Pindilli 